Available online on 15.11.2020 at http://jddtonline.info
Open Access to Pharmaceutical and Medical Research
unrestricted non-commercial use, provided the original work is properly cited

Open 1 Access

Research Article

\title{
Effect of Aqueous Extract of Thonningia sanguinea on Blood Electrolytes of Broilers Chickens
}

\author{
KONAN Kouakou Severin ${ }^{*}$, MOROH Aboya Jean-Luc ${ }^{1}$, TIEKPA Wawa Justine' ${ }^{1}$, N'GUESSAN Jean-David ${ }^{2}$ \\ ${ }^{1}$ Biotechnology and Valorisation of Agroressources Laboratory, Peleforo GON COULIBALY University, Korhogo, 1328 Korhogo, Côte d'Ivoire \\ 2 Pharmacodynamic Biochemical Laboratory, University of Felix Houphouet Boigny, 22 BP 582Abidjan 22- Côte d'Ivoire
}

\begin{abstract}
The aim of the present study is to evaluate the effect of aqueous extract of Thonningia sanguinea on blood electrolytes of broiler chickens. To do this, two hundred (200) 15-day-old Hubbard broiler chickens were divided into 2 batches of 100 chickens each. The chickens in the control group (Batch C) received unsupplemented water while those in the test group (Batch E) received water supplemented with $10 \mathrm{~g} / \mathrm{L}$ of aqueous extract of T. sanguinea for one week. Then, the zootechnical parameters such as weight growth, weight gain, consumption index and the level of serum electrolytes were determined. The results of the study showed that the aqueous extract of Thonningia sanguinea improved weight growth, weight gain and consumption index. At the same time, the results also showed that T. sanguinea did not significantly (p<0.05) affect the level of blood electrolytes of broilers chickens. From the results obtained in the present study, the aqueous extract of Thonningia sanguinea could be used to improve poultry productivity without damage on blood electrolytes.
\end{abstract}

Keywords: Thonningia sanguinea; chicken broilers; Blood electrolytes; Zootechnical parameters

Article Info: Received 29 Aug 2020; Review Completed 16 Oct 2020; $\quad$ Accepted 23 Oct 2020; Available online 15 Nov 2020

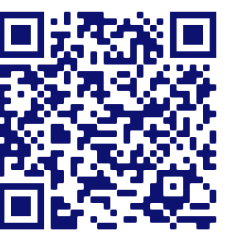

Cite this article as:

Konan KS, Moroh AJL, Tiekpa WJ, N'Guessan JD, Effect of Aqueous Extract of Thonningia sanguinea on Blood Electrolytes of Broilers Chickens, Journal of Drug Delivery and Therapeutics. 2020; 10(6):37-41

http://dx.doi.org/10.22270/jddt.v10i6.4539

*Address for Correspondence:

KONAN Kouakou Severin, Biotechnology and Valorisation of Agroressources Laboratory, Peleforo GON COULIBALY University, Korhogo, 1328 Korhogo, Côte d'Ivoire

\section{INTRODUCTION}

Poultry is an important protein source of human for these dietary qualities 1 . The poultry farming occupies a prominent place in poverty reduction strategies in developing countries 2. To optimize poultry production, farmers utilize pharmaceutical products such as antibiotic and antiparasitic to prevent outbreak of diseases. However, the search for organic products and the risk of developing resistance is directing research towards natural alternative solution such as the use of plant extracts ${ }^{3}$. Thus, several research studies have reported the beneficial effects of the use of plant extracts on avian coccidiosis 4 , bacterial diseases 5 and zootechnical performance of chickens ${ }^{6}$. Thus, studies have shown that the aqueous extract of Thonningia sanguinea improves zootechnical performance of broilers chickens 7 . However, the effect of these herbs on parameters such as blood electrolytes which are indicators of good kidney and heart health should be evaluated 8 . Thus, the aim of the present study is to evaluate the effect of aqueous extract of
Thonningia sanguinea on blood electrolytes of broiler chickens.

\section{MATERIAL AND METHODS}

\section{Plant material}

The plant material used for the study were T. sanguinea inflorescences collected at Assabou-Kouassikro, a village located in the commune of Sakassou in the center of Côte d'Ivoire. The Hubbard broilers chickens feed used in the experiment were supplied by the Ivograin Company.

\section{Preparation of the aqueous extract of $T$. sanguinea}

The inflorescences of T. sanguinea were cut and dried out of the sun for 10 days and then crushed. The aqueous extract was prepared according to the method 9. $100 \mathrm{~g}$ of $T$. sanguinea powder are added to $1 \mathrm{~L}$ of water with magnetic stirring for $48 \mathrm{~h}$. The resulting mixture is filtered and then evaporated under vacuum at $30^{\circ} \mathrm{C}$ to obtain the aqueous extract of $T$. sanguinea. 


\section{Determination of zootechnical parameters}

In order to determine the effect of the aqueous extract of $T$. sanguinea on the zootecnical parameters, 200 chicks with an average weight of $48.7 \pm 3.3 \mathrm{~g}$ were acclimatized for 2 weeks. These chicks were vaccinated against Newcastle, Gumboro and infectious bronchitis. After this acclimatization period, the chickens were divided into 2 batches of 100 chickens and numbered 1 to 100. The chickens of the control group (Batch C) have received unsupplemented water. Those of the batch E received drinking water containing $10 \mathrm{~g} / \mathrm{L}$ of aqueous extract of T. sanguinea for one week from the $22^{\text {nd }}$ to the $29^{\text {th }}$ day of age. The chickens of both batches received the same amounts of feed daily. Each week, the chickens were weighed individually along with the rest of the uneaten feed. The different weight obtained allowed us to determine the average weight, the weight gain and the consumption index of each batch according to the method 10 .

\section{Determination of serum electrolytes concentrations}

To assess the influence of $T$. sanguinea extract on certain blood electrolytes, blood samples were taken from the wing vein of chickens using a syringe. The bloods collected in heparin tube were centrifuged. The serum electrolytes $\left(\mathrm{HCO}_{3}{ }^{-}, \mathrm{Na}^{+}, \mathrm{K}^{+}, \mathrm{Cl}-\right)$ concentrations were measured using routine diagnostic techniques autoanalyser, SmartLyte (Diamond Diagnostic).

\section{Statistical analyzes}

The data obtained were analyzed with Graphpad software. 5.1. Data were expressed as mean \pm SEM. The results were analyzed using a one-way ANOVA. Treatment means were compared using Turkey's multiple comparison tests. Significance was set at $\mathrm{P} \leq 0.05$.

\section{RESULTS}

Figure 1 show the effect of the aqueous extract of $T$. sanguinea on weight growth, weight gain and consumption index. Analysis of this figure shows an increase weight growth of both batches of chickens. However, the chickens that received the aqueous extract $T$. sanguinea showed the greatest weight growth at the 29th day. At the end of the study, the mean weight of the treated chickens (batch E) was significantly $(p<0.05)$ higher than that of the chickens of the control group (batch $\mathrm{C}$ ). This increase weight increase from the $29^{\text {th }}$ day was justified by the greater weight gain ( $p$ $<0.05$ ) of the treated chickens compared to the control (figure 2). The weight gain obtained on the 43rd day was $400.6 \pm 84 \mathrm{~g}$ for Batch E against $315.5 \pm 52 \mathrm{~g}$ for the control batch.

The consumption index obtained of treated chickens was lower than that of untreated chickens from $29^{\text {th }}$ day until the end of the study (figure 3).

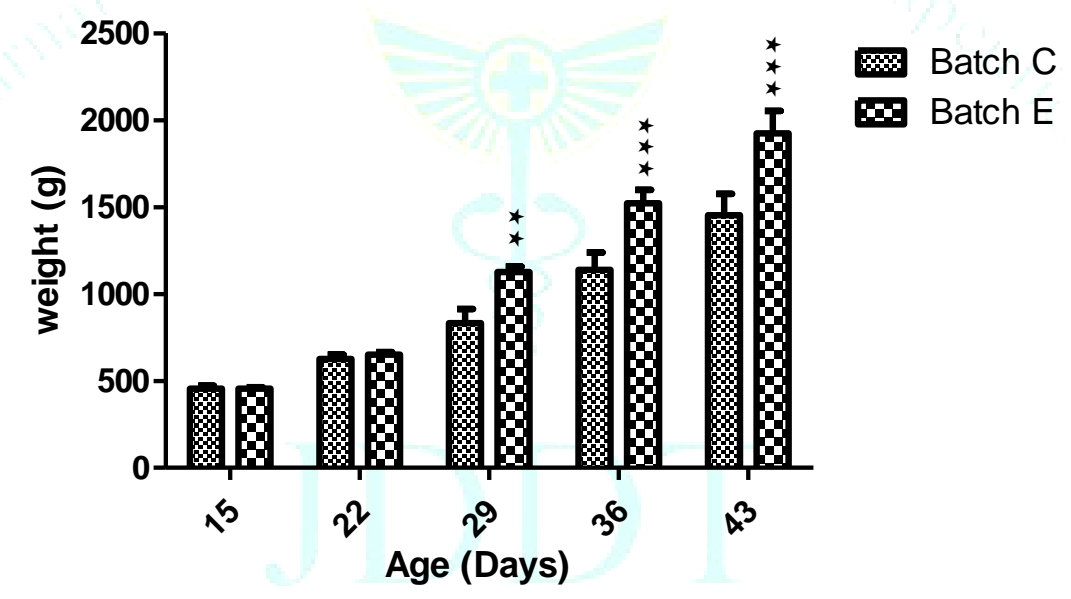

Figure 1: Body weight growth. Values are expressed as mean \pm SEM $\left(n=100 ;{ }^{* *}\right.$ significant difference $\mathrm{p}<0.01$ compared to control group ; ${ }^{* * *}$ significant difference $\mathrm{p}<0.001$ compared to control group

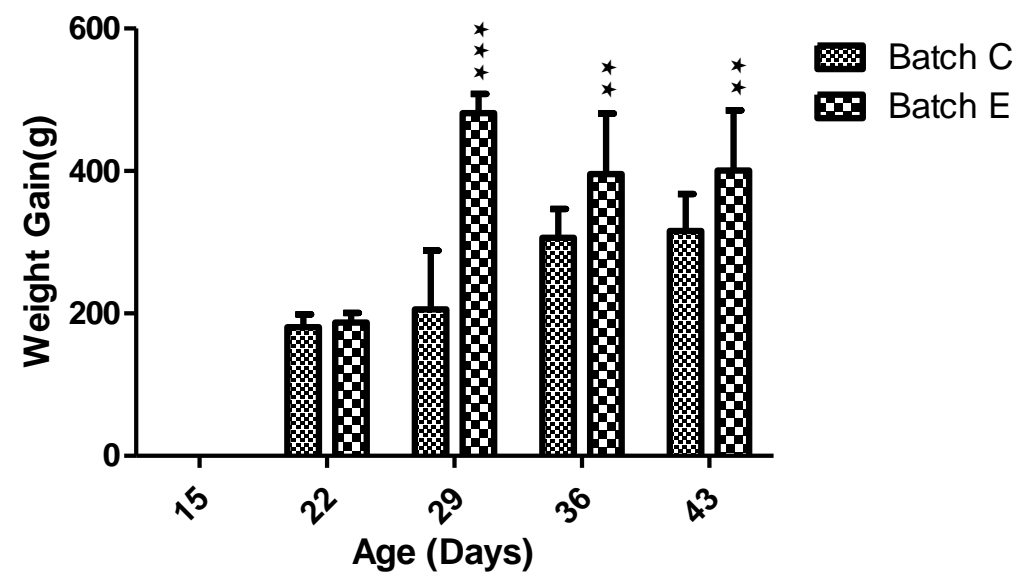

Figure 2 : Body weight gain. Values are expressed as mean \pm SEM $(n=100) ;{ }^{* *}$ significant difference $\mathrm{p}<0.01$ compared to control group ; ${ }^{* * *}$ significant difference $\mathrm{p}<0.001$ compared to control group 


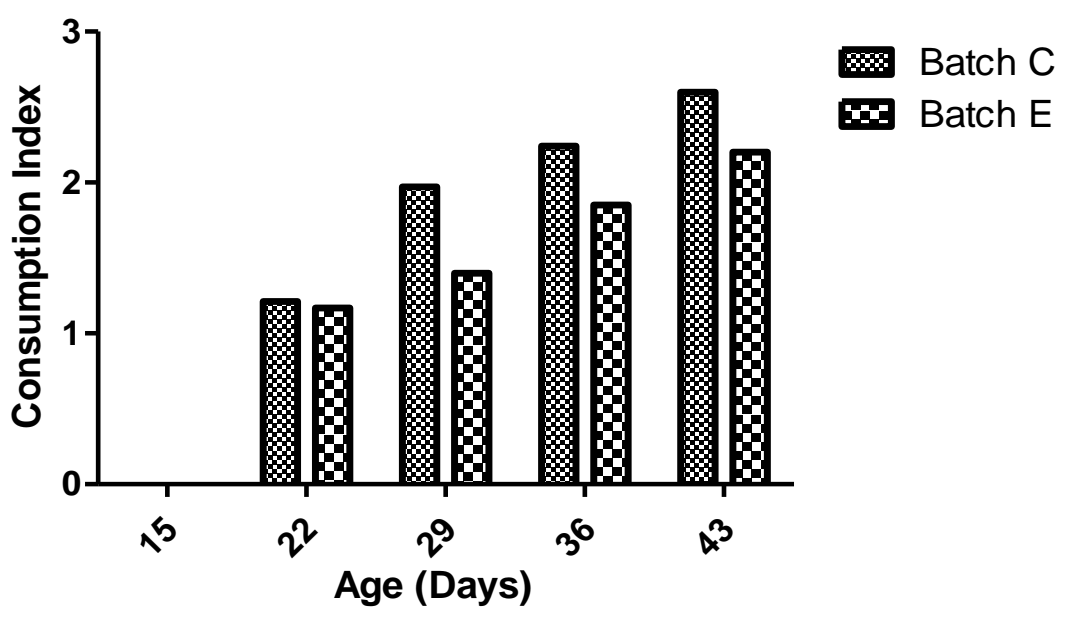

Figure3 : Consumption index

Figure 4 shows the effect of the aqueous extract of T. sanguinea on serum bicarbonate ion concentrations of broilers during the study. The analysis of this figure indicates that the blood bicarbonate level of the treated chickens did not vary significantly ( $p$ $<0.05$ ) from the control group during the study. The data in figure 5 presents the sodium ion concentration of normal chickens and the treated broilers chickens. Those results show no difference $(p<0.05)$ between the treated chickens $(b a t c h E)$ and the untreated chickens (batch C) during the period of experimentation. The figure 6 and 7 show the concentration of potassium and chloride ion of the broilers chickens. The serum electrolytes $\left(\mathrm{K}^{+}\right.$and $\left.\mathrm{Cl}-\right)$ of treated chickens showed no significant difference compared to the normal control group.

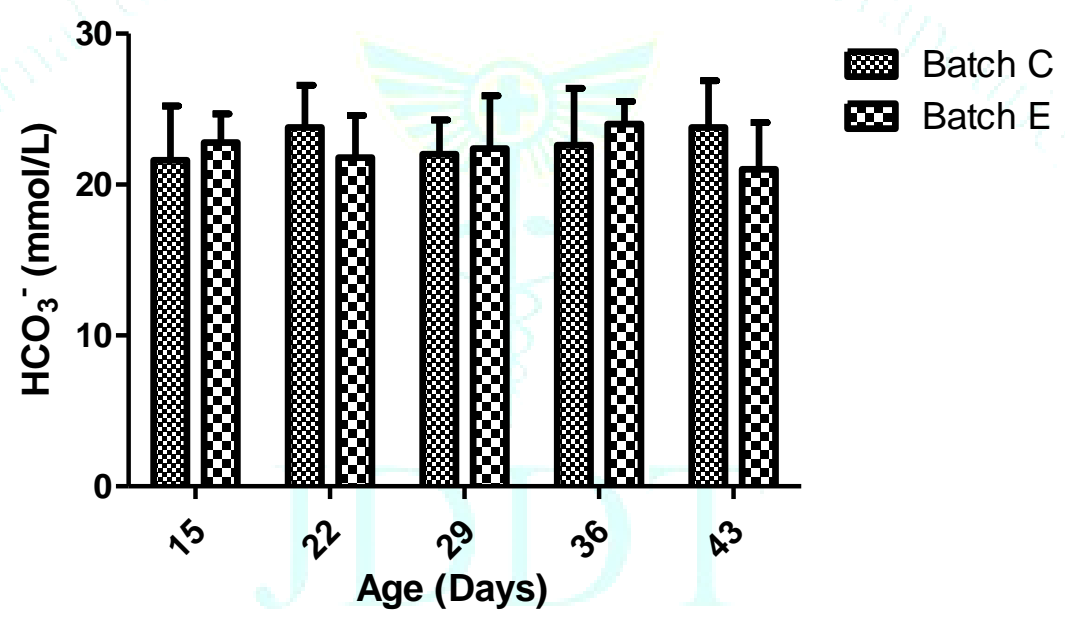

Figure 4: Effect of the aqueous extract of T. sanguinea on serum bicarbonate ion concentrations

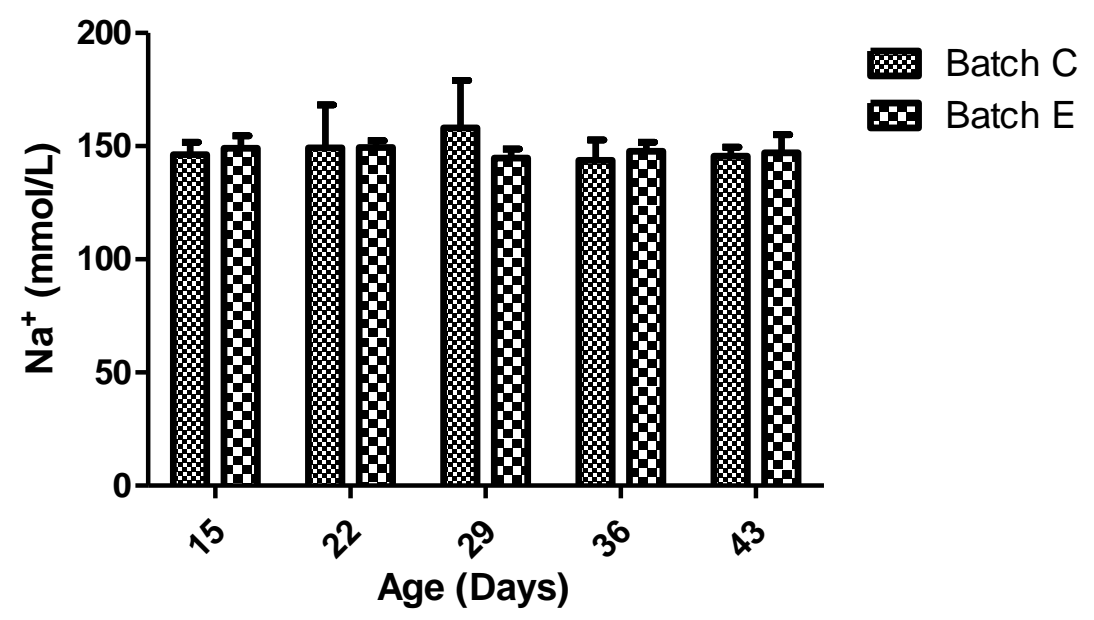

Figure 5: Effect of the aqueous extract of T. sanguinea on serum sodium ion concentrations 


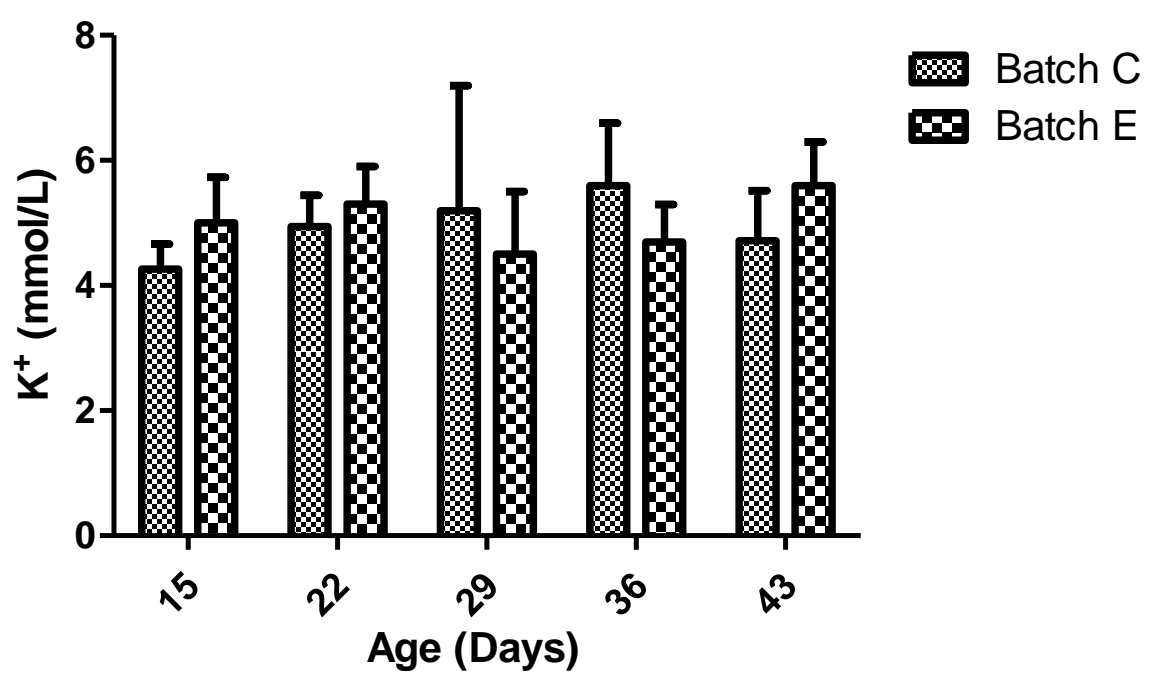

Figure 6: Effect of the aqueous extract of T. sanguinea on serum potassium ion concentrations

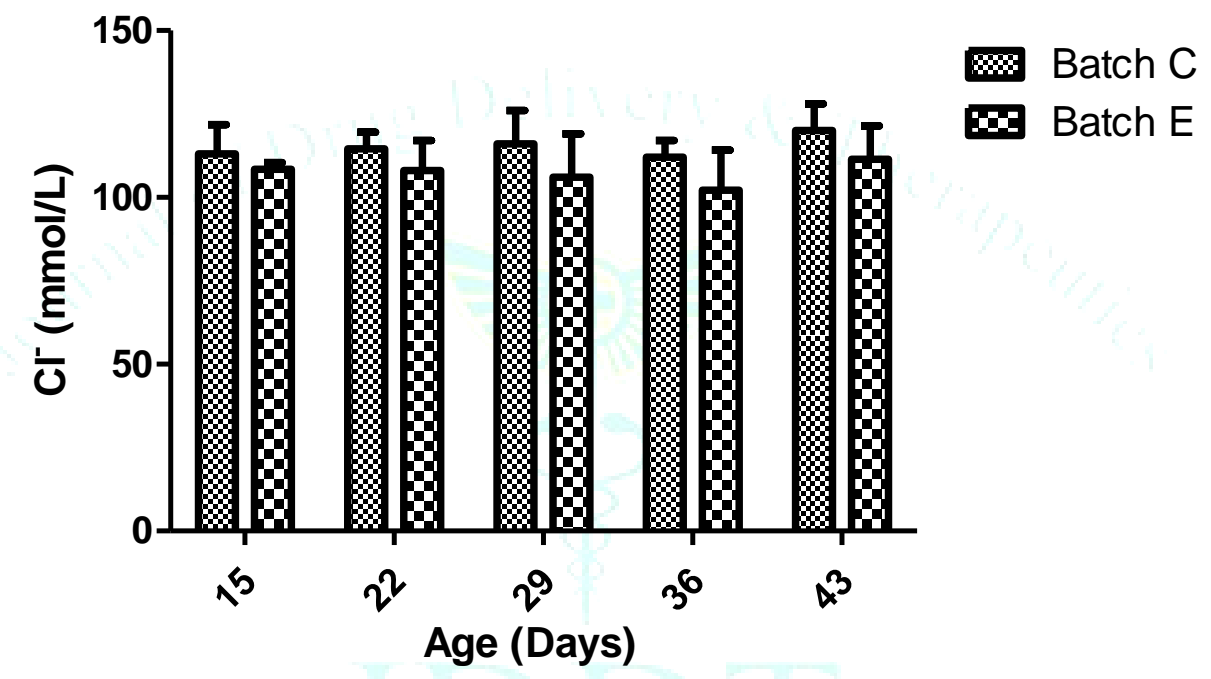

Figure 7: Effect of the aqueous extract of $T$. sanguinea on serum Chloride ion concentrations

\section{DISCUSSION}

The aim of the present study was to evaluate the effect of aqueous extract of $T$. sanguinea on blood electrolytes of broilers chickens. During this study, zootechnical parameters such as weight growth, weight gain and consumption index were also determined. The results obtained showed that the chickens treated with the aqueous extract of $T$. sanguinea had the best growth and weight gain and the lowest feed index. These results agreed with those found who demonstrated that supplementation of layer feed with aqueous extract of $T$. sanguinea improved carcass characteristics 11 . In addition, those works reported that supplementation of the feed with aqueous extract of Moringa oleifera leaves improves weight growth as well as weight gain of Hubbard broiler chickens ${ }^{1}$. These results could be explained by antibacterial 7 and antiparasitic ${ }^{12}$ properties of T. sanguinea. Indeed, the uncontrolled proliferation of the intestinal flora negatively impacts nutrient digestion and absorption and decrease the weight growth. The results also showed that supplementation of the feed with aqueous extract of $T$. sanguinea did not significantly alter the level of blood electrolytes in broilers. These results were agreed with those works who reported that supplementing the water of chickens with $10 \mathrm{~g} / \mathrm{L}$ of aqueous extract of $T$. sanguinea did not modify the biochemical parameters such as ASAT, ALT, CPK and LDH 10.

In addition, the supplementation of wistar rats food with aqueous extract of Aspilia africana leaves did not negatively impact blood electrolytes concentrations 13. Several researchers demonstrated in their studies that the roots of Terminalia schimperiana and the leaves of Ficus capensis did not significantly affect the level of blood electrolytes of rats 14,15 . These results could be explained by the antioxidant properties of T. sanguinea of molecules such as polyphenols and flavonoids 16. Indeed, phytomolecules such as flavonoids, polyphenols and gallic acid have a renal protective property 17,18 . However, our results disagreed with those works who reported that the aqueous extract of Momordica charantia and Syzygium cumini modified potassium and sodium levels of diabetic rats ${ }^{19}$. In addition, the aqueous extract of Nigella sativa and Ocimum gratissimum decreases blood electrolyte levels in a renal toxicity study of wistar rats 20 . 


\section{CONCLUSION}

The study showed that supplementing water with $10 \mathrm{~g} / \mathrm{L}$ of $T$. sanguinea extract improved body weight growth as well as weight gain and reduced the drinking index. In addition, supplementation does not significantly modify the level of the blood electrolytes studied. In view of these results of the present study, the aqueous extract could be used to improve the productivity of broiler chickens.

\section{CONFLICT OF INTEREST}

The authors declare no conflict of interest

\section{REFERENCES}

1 Abasse T, Maigachi I, Habba W, Diallo D, "Effect of supplementing the flour of Moringa oleifera (Lam.) Leaves in the production of broilers in Niger" Int J Biol Chem Sci, 2017; 11(2):722-729

2 Mingoas KJP, Awah-Ndukum J, Mampom BJ, Mfopit MY, Zoli PA, "Effets du système d'élevage sur les performances zootechniques et les paramètres sanguins et biochimiques chez les poulets de chair en zone péri-urbaine de Ngaoundéré, Cameroun", J Anim Plant Sci, 2017; 32 (1):5079-5094

3 Emanfo ASA, Komoin-Oka C, Koné MW, Esmel ME, "Anti-coccidian effect of almonds of Azadirachta indica (Meliaceae) against Eimeria sp. of the dwarf goat" Int J Agron Agr Res, 2017;10(1):52-59.

4 Lee YS, Lee SH, Gadde UD, Oh ST, Lee SJ, Lillehoj HS, "Allium hookeri supplementation improves intestinal immune response against necrotic enteritis in young broiler chickens" Poult Sci, 2018; 97(6):1899-908.

5 Dinzedi MR, Okou O, Moevi A, Nathalie GK, Touré D, Nguessan JD, Dosso M, Djaman AJ, "Anti Staphylococcus aureus Activity of the Aqueous Extract and Hexanic Fraction of Thonningia sanguinea (Cote d'Ivoire)", IJPPR, 2015; 7(2):301-306.

6 Sahraoui N, Larbi R, Lakhdar M, Errahmani MB, Guetarni D, Hornick JL, "Impact of a plant extract "Origanum Majorana" on the zootechnical parameters and health status of broiler chicken" Rev Ma. Sc. Agron Vet, 2016; 4(3):72-77.

7 Kamagaté T, Ouattara A, Ouattara K, Sanogo M, Saraka ND, Ouattara L, Coulibaly A, "Therapeutic activity of Thonningia sanguinea aqueous extract, Vahl on an experimental colibacillosis in chicken" J Phytopharmacol, 2017; 6:282-287

8 Uhegbu FO, Nwaogwugwu CJ, OnwuegbuchulamCH, Oriaku CE, Atasie OC, Akatobi KU, "Renal Protective Properties of Aqueous Extract of Bryophyllum pinnatum (Lam.) Oken Leaf against Petrol Vapour - Induced Toxicity on Male Albino Rats". Eur J Med Plants, 2017; 19(3):1-8

9 Ouattara K, Coulibaly A, N'guessan JD, Djaman AJ, "GuedeGuina F. Thonningia sanguinea anti-diarrheal activity (THOS) on
Salmonella enterica serotype Enteritidis lysotype 6 infections in laying hens" Rev Ivoi Sci Tech, 2005; 6:151-160.

10 Konan KS, Toure D, Toure A, N'guessan JD, "Effect of Thonningia sanguinea (Balanophoraceae) on zootechnical and biochemical parameters of broiler chickens" J Phytopharmacol, 2020; 9(2):115-119

11 Yao KA, N'dri AL, Konan KS, Toure A, Coulibaly M, N'Guessan JD, "Effect of dietary supplementation of THOS (aqueous extract of Thonningia saguinea) on carcass characteristics and on some physicochemical parameters in pectoral and thigh muscles of isa brown laying hens" Int J Adv Res, 2017; 5(10):368-379

12 Thomford AK, Abdelhameed RFA, Yamada K, "Chemical studies on the parasitic plant Thonningia sanguinea Vahl" RSC Adv, 2018; 8:21002-21011.

13 Arunsi UO, Chinyere GC, Ngwogu KO, ID , Ngwogu AC, Atasie OC, ID , Oti UA, AkojuobiJK, Udeogu C, Ibe C, "Evaluation of the biochemical, haematological and histopathological parameters of female Wistar rats fed with aqueous and ethanol extracts of Aspilia africana leaves" J Herbmed Pharmacol, 2020; 9(3):257267.

14 Awotunde OS, Adewoyeb SO, Dhanabal PSC, Hawumba J, "Subacute toxicity study of aqueous root extract of Terminalia schimperiana in male Wistar rats" Toxicology Reports, 2019; 6:825-832

15 Ezeigwe OC, Nzekwe FA, Nworji OF, Ezennaya CF, Iloanya EL, Asogwa KK, "Effect of Aqueous Extract of $F$. capensis Leaves and its Combination with $C$. aconitifolius Leaves on Essential Biochemical Parameters of Phenylhydrazine-Induced Anemic Rats" J Exp Pharmacol, 2020; 12 :191-201

16 Pompermaier L, Schwaiger S, Mawunu M, Lautenschlaeger T, Stuppner H, Faure K, "Purification of thonningianins A and B and four further derivatives from Thonningia sanguinea by oneand two-dimensional centrifugal partition chromatography" $J$ Sep Sci, 2020; 43:524-530

17 Shah NA, Khan MR, Nigussie D, "Phytochemical investigation and nephroprotective potential of Sida cordata in rat" $B M C$ Complement Altern Med, 2017; 17(1):388.

18 Mazani M, Mahmoodzadeh Y, Asl MC, Banaei S, Rezagholizadeh L, Mohammadnia A, "Renoprotective effects of the methanolic extract of Tanacetum parthenium against carbon tetrachlorideinduced renal injury in rats" Avicenna J Phytomed, 2018; 8 (4):370-379.

19 Sirisha K, Navya G, Shirisha Y, Girija P, Venkateshwarlu K, "Effect of Momordica charantia and Syzygium cumini extract on serum electrolytes in alloxan induced diabetic rats", Int J Pharm Pharm Sci, 2018; 10(11):24-27

20 Okoye FN, Benjamin P, "Effects of Aqueous Extracts of Nigella sativa and Ocimum gratissimum on Electrolyte, Urea, Creatinine of Wistar Rat" JALSI, 2019; 21(3): 1-8. 